\title{
Effects of peptide YY (PYY) on mouth to caecum intestinal transit time and on the rate of gastric emptying in healthy volunteers
}

\author{
A P SAVAGE, T E ADRIAN, G CAROLAN, V K CHATTERJEE, \\ AND S R BLOOM
}

From the Department of Medicine and Medical Physics, Royal Postgraduate Medical School, Hammersmith Hospital, Du Cane Road, London

SUMmary The effect of an infusion of two doses of peptide YY (PYY), a novel putative gastrointestinal hormone, has been assessed on mouth to caecum intestinal transit time and on the rate of gastric emptying after ingestion of an inert $200 \mathrm{ml}$ liquid meal thought unlikely to interrupt fasting gastrointestinal motility patterns. A low dose of PYY was chosen to give plasma concentrations within the range seen postprandially in healthy subjects, while the high dose mimicked the raised levels seen in several malabsorptive conditions. During infusion of PYY at $0 \cdot 18 \mathrm{pmol} / \mathrm{kg} / \mathrm{min}$ plasma concentrations rose from a basal of $8 \pm 2 \mathrm{pmol} / \mathrm{l}$ to $38 \pm 5 \mathrm{pmol} / \mathrm{l}$ and at $0 \cdot 51$ $\mathrm{pmol} / \mathrm{kg} / \mathrm{min}$ to $87 \pm 10 \mathrm{pmol} / \mathrm{l}$. Mouth to caecum transit time was delayed from $67 \pm 4 \mathrm{mins}$ on the saline infusion day to $94 \pm 7$ mins $(p<0.01)$ on the low dose and $192 \pm 9$ mins $(p<0.001)$ on the high dose infusion day. Time to $50 \%$ gastric emptying was prolonged from $37 \pm 8$ mins during saline infusion to $63 \pm 10$ mins $(p<0 \cdot 05)$ during low and $130 \pm 12$ mins $(p<0 \cdot 001)$ during high dose infusion. Thus the infusion of PYY shows a dose related inhibition of mouth to caecum intestinal transit time and of the rate of gastric emptying and suggests this novel hormonal peptide to be of importance in gastrointestinal physiology.

Peptide YY (PYY) is a 36 amino acid gastrointestinal hormonal peptide first isolated from porcine small bowel in $1980 .^{12}$ It shares considerable sequence homology with pancreatic polypeptide and neuropeptide Y (NPY). ${ }^{23}$ Immunocytochemical studies have shown PYY to be localised to the endocrine cells in the monkey (Macaca rhesus) and human gastrointestinal tract, and these are found to be most numerous in the ileal, colonic, and rectal mucosa. ${ }^{45}$ Peptide YY has been reported to be co-localised with enteroglucagon in the L cells. ${ }^{77}$

Peptide YY is released into the circulation by food, rising from basal levels of $8 \mathrm{pmol} / \mathrm{l}$ to a mean plateau of $28 \mathrm{pmol} / \mathrm{l}$ after an 870 calorie meal and $53 \mathrm{pmol} / \mathrm{l}$ after a 4500 calorie meal. ${ }^{8}$ The pharmacological activities of PYY include the inhibition of jejunal and

Address for correspondence: Professor S R Bloom, Department of Medicine, Royal Postgraduate Medical School, 2nd Floor Francis Fraser Labs, Hammersmith Hospital, Du Cane Road, London W12 0HS.

Received for publication 13 June 1986. colonic motility, ${ }^{9}$ of pancreatic secretion in the cat ${ }^{2}$ and of the interdigestive contractions of the canine stomach. ${ }^{11}$ In man, low dose infusion of PYY inhibits pentagastrin stimulated gastric acid secretion but not pancreatic secretion." Peptide YY also delays the rate of gastric emptying of a glucose drink. ${ }^{12}$ The study reported here was undertaken to determine in normal volunteers the effect of PYY infusion in physiological levels on total mouth to caecum intestinal transit time and rate of gastric emptying. An assessment of effect on small intestinal transit was made by subtracting the time to $50 \%$ gastric emptying from total mouth to caecum transit time.

\section{Methods}

SUBJECTS

This study had the prior approval of the Hammersmith Hospital and Royal Postgraduate Medical School ethical committee and all volunteers gave informed consent. The rate of gastric emptying and 
the total mouth to caecum intestinal transit time was measured in seven healthy male volunteers after an inert liquid isotonic 'meal' of $200 \mathrm{ml}$ water, $30 \mathrm{~g}$ lactulose (Duphalac, Duphar, Southampton) and $100 \mu \mathrm{Ci}(3.7 \mathrm{MBq}) \mathrm{Tc} 99^{\mathrm{m}}$ tin colloid (Amersham International plc code N112). Each volunteer underwent three separate studies, receiving in random order infusions of saline (control), $0.4 \mathrm{pmol} / \mathrm{kg} / \mathrm{min}$ synthetic PYY (Bachem, USA) (low dose), or 1.1 $\mathrm{pmol} / \mathrm{kg} / \mathrm{min}$ PYY (high dose). The peptide was reconstituted in $50 \mathrm{ml}$ physiological saline for infusion (Boots plc, Nottingham, UK) containing 1\% human serum albumin (HSA) (Blood Products Lab, Elstree, UK). In the case of the control infusion $1 \%$ HSA was added to the saline infusate. The minimum time interval between tests was seven days. The subjects were unaware at the time of the nature of each infusion.

On each occasion, the subject attended after an overnight fast and was seated in front of a gamma camera (IGE Maxi camera 400) connected to a computer for data analysis (Nodecrest Medical Systems Micas 1000). An indwelling intravenous cannula was placed in an antecubital vein of each arm. Three basal blood samples were taken at 15 minute intervals before the start of the infusion and at 15 minute intervals throughout the course of the study. The volunteers drank the meal 30 minutes after the start of the infusion of either peptide or saline. Collection of scintigraphic data started immediately by integration of counts over the area of the stomach in two minute intervals and storage of digital data on magnetic tape. The selection of the stomach area was based on the distribution of activity during the first eight minutes after ingestion of the isotope by two observers who were unaware of the nature of the infusion. The rate of loss of radioactivity from the stomach area after correction for decay of the isotope gave the rate of gastric emptying.

Mouth to caecum transit time was measured by the breath hydrogen technique. ${ }^{1314}$ Samples of exhaled air were taken at five minute intervals via a modified Haldane-Priestly tube starting at the time of the infusion and immediately analysed for hydrogen using a breath hydrogen monitor (GMI, Renfrew, Scotland). Mouth to caecum intestinal transit time was calculated as the time to half rise from basal to plateau levels of excreted breath $\mathrm{H}_{2}$. An estimate of small intestinal transit was made by subtracting the time to $50 \%$ gastric emptying from mouth to caecum intestinal transit time.

\section{HORMONE ASSAYS}

Whole blood was placed in a lithium heparin tube containing $400 \mathrm{KIU}$ aprotinin per millilitre and centrifuged immediately for 10 minutes at $1000 \mathrm{~g}$.
Plasma was separated within 15 minutes of sampling and frozen immediately on dry ice before storage at $-20^{\circ} \mathrm{C}$ pending assay. Samples of the infusate were taken from the catheter tip after infusion, frozen, and stored as above. Peptide YY was assayed in duplicate by specific radioimmunoassay described in detail elsewhere. ${ }^{8}$ The assay was able to detect changes in PYY of $2 \mathrm{pmol} / \mathrm{l}$ with $95 \%$ confidence and showed less than $0.01 \%$ crossreaction with the related peptides, neuropeptide $\mathrm{Y}$ and pancreatic polypeptide.

\section{STATISTICAL ANALYSIS}

Results are expressed as the mean \pm standard error of the mean. Student's paired $t$ test was used for comparison of PYY infusion levels, mouth to caecum transit time and gastric emptying data. Least squares linear regression analysis was used to correlate PYY levels with mouth to caecum transit.

\section{Results}

Volunteers were unable to distinguish between the saline and peptide infusions which were well tolerated. Peptide YY concentrations measured at the catheter tip were $0 \cdot 18 \pm 0 \cdot 1 \mathrm{pmol} / \mathrm{kg} / \mathrm{min}$ at the end of the low dose infusion, and $0.51 \pm 0.09 \mathrm{pmol} / \mathrm{kg} / \mathrm{min}$ at the end of the high dose infusion. There was an apparent loss of $55 \%$ of the peptide between the calculated dose and the measured dose. No PYY immunoreactivity was detected in the saline infusion. Plasma PYY concentrations during the saline infusion showed a non-significant rise from $8 \cdot 0 \pm 2 \cdot 0$ $\mathrm{pmol} / \mathrm{l}$ at $-30 \mathrm{mins}$ to $12 \cdot 6 \pm 3 \mathrm{pmol} / \mathrm{l}$ at $135 \mathrm{mins}$. During the last hour of the PYY infusion, PYY concentrations rose to $38.0 \pm 5.5 \mathrm{pmol} / \mathrm{l}$ during low dose infusion and $87.5 \pm 9.7 \mathrm{pmol} / \mathrm{l}$ during the high dose infusion (Fig. 1).

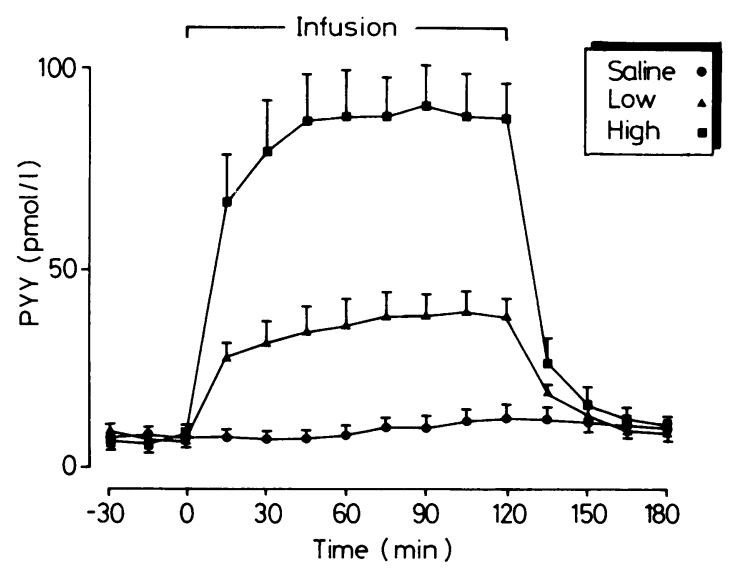

Fig. 1 Plasma PYY concentrations during the course of the study (mean $\pm S E M)$. The meal was given at 30 minutes. 
Mouth to caecum intestinal transit was delayed by PYY infusion from $67 \pm 4$ mins during the saline infusion to $94 \pm 7$ mins during low dose infusion $(\mathrm{p}<0.01)$ and $192 \pm 9$ mins during high dose infusion $(p<0.001$, Fig. 2). The rate of gastric emptying was also considerably slowed by both low and high dose PYY infusion (Fig. 3). Only $14 \pm 3 \%$ of initial radioactivity remained in the stomach area after 90 minutes during saline infusion while $43 \pm 7 \%$ $(p<0.05)$ and $76 \pm 8 \%(p<0.001)$ of initial radioactivity remained during low and high dose infusion respectively. Time to $50 \%$ gastric emptying was similarly delayed from $37 \pm 8$ mins during the saline infusion to $63 \pm 10$ mins $(p<0.05)$ and $130 \pm 12$ mins $(p<0.001)$ during low and high dose infusion respectively (Fig. 4). There was a positive correlation between individual peak PYY concentrations and mouth to caecum transit time $(r=0.80, p<0.001)$ (Fig. 5) and time to $50 \%$ gastric emptying $(r=0.55$, $\mathrm{p}<0.05$ ) (Fig. 6). Similarly, there was a positive correlation between time to $50 \%$ gastric emptying and mouth to caecum intestinal transit $(r=0.81$, $\mathrm{p}<0.001)$. Small intestinal transit, as assessed by subtracting time to $50 \%$ gastric emptying from mouth to caecum transit, was $30 \pm 7$ mins during the saline infusion and was prolonged to $42 \pm 9$ mins (NS) and $62 \pm 13$ mins $(p<0.05)$ during low and high dose PYY infusion respectively.

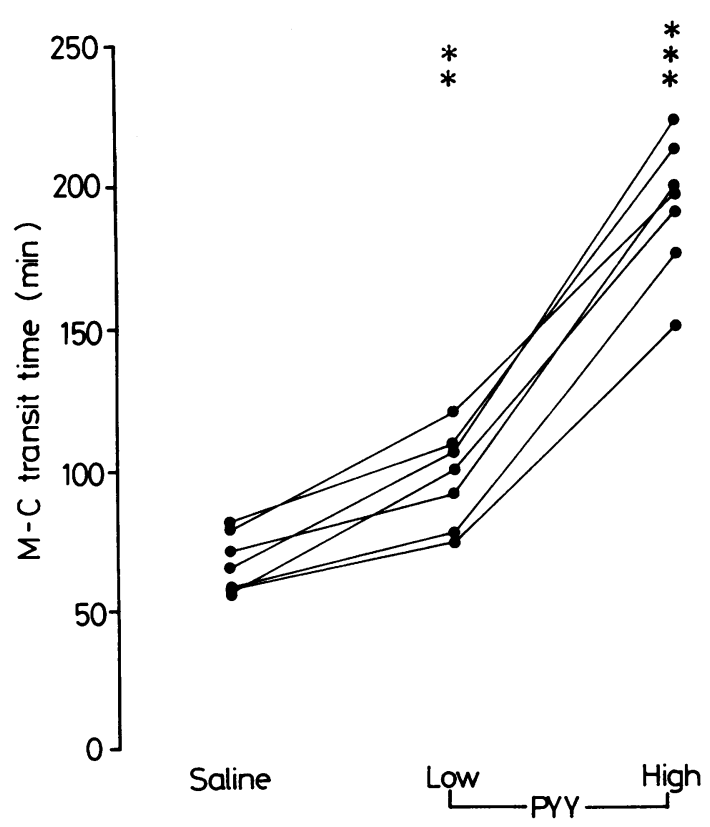

Fig. 2 Mouth to caecum intestinal transit during saline, low and high dose PYY infusion $\left.\left({ }^{* *}=p<0.01\right),{ }^{* * *}=p<0.001\right)$ vs saline group).

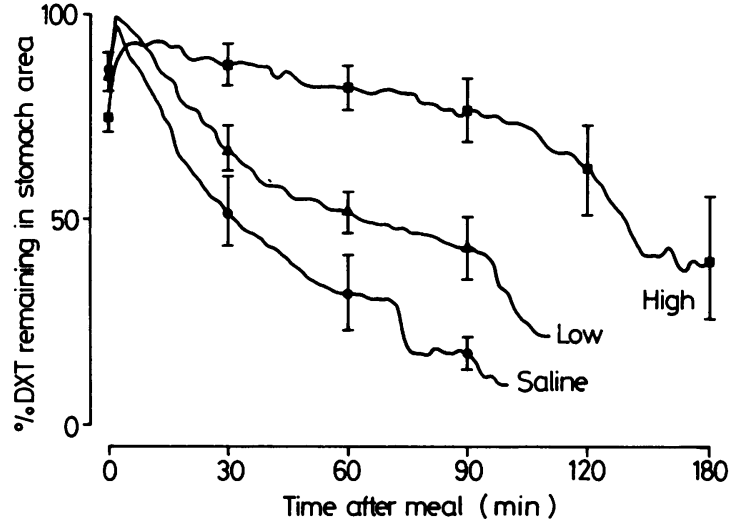

Fig. 3 Gastric emptying curves during saline, low and high dose PYY infusion.

\section{Discussion}

The plasma PYY response to nutrient stimuli given orally is maximal with a fat meal. ${ }^{8}$ Previous studies have shown that ileal infusion of intralipid results in a delay in gastric emptying, small bowel transit and mouth to caecum transit unrelated to the release of enteroglucagon or neurotensin. ${ }^{15}{ }^{16}$ While PYY levels were not measured in these studies, it is probable that PYY was released. This study shows that infusion of

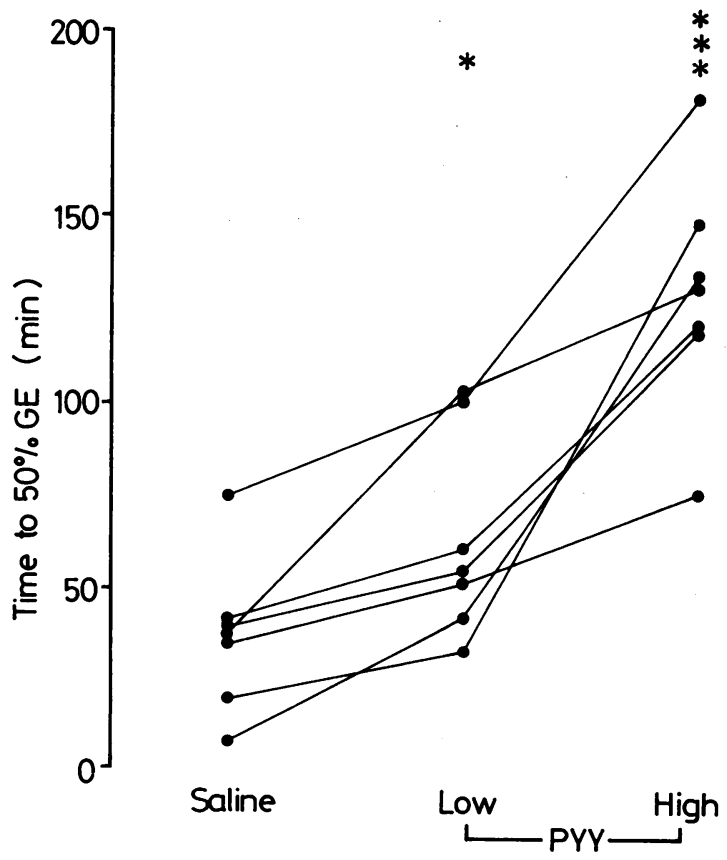

Fig. 4 Time to $50 \%$ gastric emptying during PYY infusion. $\left({ }^{*}=p<0.05,{ }^{* * *}=p<0.001\right.$ vs saline group $)$. 


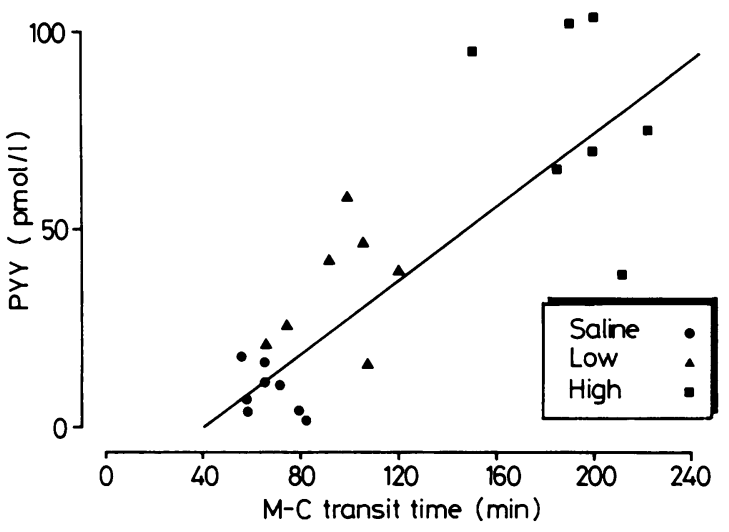

Fig. 5 Correlation between mouth-caecum intestinal transit and PYY concentrations. $(r=0 \cdot 80, p<0 \cdot 001)$.

PYY into normal volunteers can cause delay of mouth to caecum intestinal transit. The meal chosen for the study was designed to be 'inert' in that it was isotonic and there was no nutrient content. This was to minimise the effect of endogenous release of PYY and other gastrointestinal hormones that would result from ingestion of a nutrient meal. It was considered likely that volunteers were studied in the fasting state, although there was no direct evidence for this, as this small volume meal is unlikely to interrupt fasting gastrointestinal motility patterns. In the studies on infusion of fat into the terminal ileum, there was a change in the pattern of gastrointestinal pressure activity from the fasting to the fed state. ${ }^{16}$ The regulation of gastrointestinal motility and intestinal transit are thought to be different in the fasted and fed state and it is not therefore possible to draw a direct comparison between these studies and the one reported in this paper.

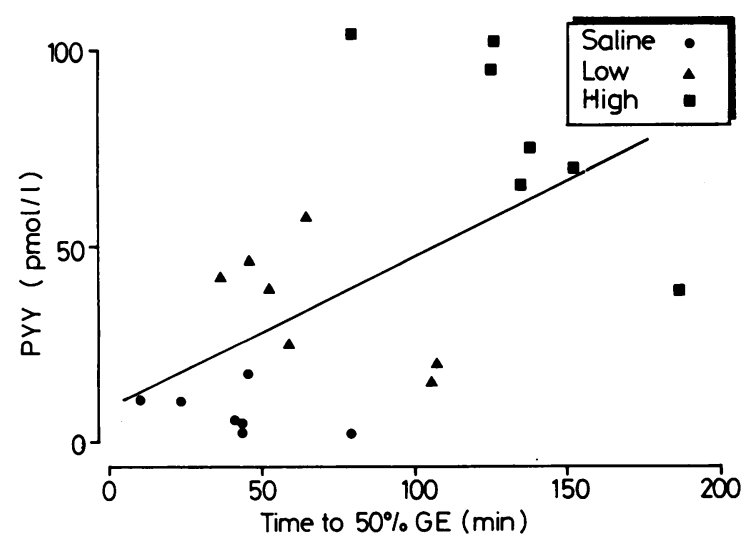

Fig. 6 Correlation between time to $50 \%$ gastric emptying and PYY concentrations. $(r=0.55, p<0.05)$.
The low dose tested was within the physiological range in that the peak level of $38 \mathrm{pmol} / \mathrm{l}$ was comparable with the mean concentration of $28 \mathrm{pmol} / 1$ seen after an 870 calorie lunch and that seen after a large evening meal of $53 \mathrm{pmol} / \mathrm{l}$, all as measured by the same radioimmunoassay. ${ }^{8}$ The higher dose resulted in peak levels of $86 \mathrm{pmol} / \mathrm{l}$ which was above the physiological range but certainly within the range seen in patients, for example with tropical sprue. ${ }^{17}$ Both infusion levels showed a significant slowing of mouth to caecum intestinal transit and this was dose responsive.

Intravenous infusion of PYY resulting in an incremental rise of $52 \mathrm{pmol} / \mathrm{l}$ as measured with a less specific radioimmunoassay has previously been shown to inhibit the rate of gastric emptying of a glucose drink in man. ${ }^{12} \mathrm{~A}$ possible explanation for the differences in rate of gastric emptying reported here and previously is that, in this study, volunteers were thought to be in the fasted state. Previous reports in animals have shown an inhibitory effect of PYY on canine gastric motility ${ }^{10}$ but only on the interdigestive migrating contractions, and not on postprandial contractile activity. A small but significant fall in motilin has been reported during PYY infusion..$^{18}$ As infusion of physiological doses of motilin enhances gastric emptying, ${ }^{19}$ the motor effects of PYY may in part be caused by suppression of motilin release.

The profound effect of PYY infusion on gastric emptying suggests that it may be a major factor in mouth to caecum intestinal transit time. Previous studies using a solid meal have not shown a positive correlation between mouth to caecum intestinal transit and the time to $50 \%$ gastric emptying suggesting that rate of small intestinal transit may not depend on rate of gastric emptying. ${ }^{20} \mathrm{We}$ have shown a positive correlation between time to $50 \%$ gastric emptying and mouth caecum intestinal transit, however, possibly related to the study of volunteers thought to be in the fasting rather than the fed state. Subtraction of time to $50 \%$ gastric emptying from mouth to caecum intestinal transit time may give an estimate of small intestinal transit and suggests the possibility that PYY may also delay small intestinal transit.

Further support for a role for PYY in gastrointestinal motility comes from the finding of rapid intestinal transit in patients after proctocolectomy for ulcerative colitis where there was a correlation between length of ileum resected and increased rate of intestinal transit. ${ }^{21}$ In addition, output from ileostomies is significantly greater if the terminal ileum is resected. ${ }^{22} 23$ As PYY is distributed distally in the gastrointestinal tract with only very low levels found proximal to the ileum, proctocolectomy with resection of the terminal ileum would be expected to 
reduce release of PYY and we speculate that the putative faster transit may also be a factor contributing to ileostomy diarrhoea. After small bowel resection in the rat, PYY levels are raised ${ }^{24}$ and this is a possible mechanism for the adaptive slowing of gastrointestinal transit previously reported after intestinal resection. ${ }^{25}$

In conclusion, this study shows that infusion of PYY in physiological and pathophysiological doses delays both mouth to caecum intestinal transit time and the rate of gastric emptying of an inert liquid meal.

Mr A P Savage is supported by the Medical Research Council which provided funding for this project. We would like to thank Ms A George for preparing the artwork.

\section{References}

1 Tatemoto K, Mutt V. Isolation of two novel candidate hormones using a chemical method for finding naturally occurring polypeptides. Nature 1980; 285: 417-8.

2 Tatemoto $\mathrm{K}$. Isolation and characterization of peptide YY (PYY), a candidate gut hormone that inhibits pancreatic exocrine secretion. Proc Natl Acad Sci USA 1982; 79: 2514-8.

3 Tatemoto K, Carlquist M, Mutt V. Neuropeptide Y - a novel brain peptide with structural similarities to peptide YY and pancreatic polypeptide. Nature 1982; 296: 659-60.

4 El-Salhy M, Grimelius L. Immunocytochemical demonstration of polypeptide YY (PYY) in the gastrointestinal tract of the monkey, macaca rhesus: light and electron microscopic study. Biomed Res 1983; 4: 289-4.

5 El-Salhy M, Grimelius L, Wilander E, et al. Immunocytochemical identification of polypeptide YY (PYY) cells in the human gastrointestinal tract. Histochemistry 1983; 77: 15-23.

6 Ali-Rachedi A, Varndell IM, Adrian TE, et al. Peptide YY (PYY) immunoreactivity is co-stored with glucagonrelated immunoreactants in endocrine cells of the gut and pancreas. Histochemistry 1984; 80: 487-91.

7 Bottcher G, Sjolund K, Ekblad E, Hakanson R, Schwartz TW, Sundler F. Co-existence of peptide YY and glicentin immunoreactivity in endocrine cells of the gut. Regul Pept 1984; 8: 261-6.

8 Adrian TE, Ferri G-L, Bacarese-Hamilton ÅJ, Fuessl HS, Polak JM, Bloom SR. Human distribution and release of a putative new gut hormone, peptide YY (PYY). Gastroenterology 1985; 89: 1070-7.

9 Lundberg JM, Tatemoto K, Terenius L, et al. Localisation of peptide YY (PYY) in gastrointestinal endocrine cells and effects on intestinal blood flow and motility. Proc Natl Acad Sci USA 1982; 79: 4471-5.
10 Suzuki T, Nakaya M, Itoh Z, Tatemoto K, Mutt V. Inhibition of interdigestive contractile activity in the stomach by peptide YY in Heidenhain pouch dogs. Gastroenterology 1983; 85: 114-21.

11 Adrian TE, Savage AP, Sagor GR, et al. Effect of Peptide YY on gastric, pancreatic and biliary function in humans. Gastroenterology 1985; 89: 494-99.

12 Allen JM, Fitzpatrick ML, Yeats JC, Darcy K, Adrian TE, Bloom SR. Effects of peptide YY and neuropeptide $\mathrm{Y}$ on gastric emptying in man. Digestion 1984; 30: 255-62.

13 Bond JH, Levitt MD. Investigation of small bowel transit time in man utilising pulmonary hydrogen $\left(\mathrm{H}_{2}\right)$ measurements. J Lab Clin Med 1975; 85: 546-55.

14 Corbett CL, Thomas S, Read NW, Hobson N, Bergman I, Holdsworth CD. Electrochemical detector for breath hydrogen determination: measurement of small bowel transit in normal subjects and patients with the irritable bowel syndrome. Gut 1981; 22: 836-40.

15 Read NW, McFarlane A, Kinsman RI, et al. Effect of infusion of nutrient solutions into the ileum on gastrointestinal transit and plasma levels of neurotensin and enteroglucagon. Gastroenterology 1984; 86: 274-80.

16 Spiller RC, Trotman IF, Higgins BE, et al. The ileal brake - inhibition of jejunal motility after ileal fat perfusion in man. Gut 1984; 25 : 365-74.

17 Adrian TE, Savage AP, Bacarese-Hamilton AJ, Wolfe K, Besterman HS, Bloom SR. Peptide YY abnormalities in gastrointestinal diseases. Gastroenterology 1986; 90: $379-84$

18 Adrian TE, Sagor GR, Savage AP, Bacarese-Hamilton AJ, Polak JM, Bloom SR. PYY infusion in man Circulatory and gastrointestinal effects. Regul Pept 1983; 7: 271.

19 Christofides ND, Modlin IM, Fitzpatrick ML, Bloom SR. Effect of motilin on the rate of gastric emptying and gut hormone release during breakfast. Gastroenterology 1979; 76: 903-7.

20 Read NW, Miles CA, Fisher D, et al. Transit of a meal through the stomach, small intestine, and colon in normal subjects and its role in the pathogenesis of diarrhoea. Gastroenterology 1980; 79: 1276-82.

21 Neal DE, Williams NS, Barker MCJ, King RFGJ. The effect of resection of the distal ileum on gastric emptying, small bowel transit and absorption after proctocolectomy. Br J Surg 1984; 71: 666-70.

22 Hill GL, Mair WSJ, Goligher JC. Impairment of 'ileostomy adaptation' in patients after ileal resection. Gut 1974; 15: 982-7.

23 Hill GL, Mair WSJ, Goligher JC. Cause and management of high volume output salt-depleting ileostomy. $\mathrm{Br}$ J Surg 1975; 62: 720-6.

24 Savage AP, Gornacz GE, Adrian TE, et al. Is raised plasma peptide $Y Y$ after intestinal resection in the rat responsible for the trophic response? Gut 1985; 26: 1353-8.

25 Nygaard K. Resection of the small intestine in rats 4 . Adaptation of gastro-intestinal motility. Acta Chir Scand 1967; 133: 407-16. 